\title{
Emotion regulation and burnout in doctors: A systematic review
}

\author{
G Jackson-Koku MBChB (Hons), LLM, BSc (Hons) ${ }^{\text {a* }}$ \\ Paul Grime MBChB FFOM MBA ${ }^{b}$
}

\begin{abstract}
a Department of Occupational Health, Cambridge University Hospitals NHS Trust, Cambridge, CB2 OQQ, UK; ' ' Guy's and St. Thomas' Occupational Health Service, 75-79 York Rd, Lambeth, London SE1 7NJ
\end{abstract}

${ }^{*}$ Correspondence author details:

Dr Gordon Jackson-Koku

Cambridge University Hospitals NHS Trust

Department of Occupational Health

Addenbrookes Hospital, Hills Road

Cambridge, CB2 OQQ

Email: gordonjackson-koku@doctors.org.uk

Tel: + 44 (0)7985 799230 


\section{Abstract:}

Background: Burnout is a pervasive health condition affecting many doctors at various stages in their careers. Characterised by emotional exhaustion, depersonalisation, and a reduced sense of personal accomplishment it can result in significant personal and professional consequences putting patient care at risk. Emotion regulation describes a capacity to self-modulate emotions to achieve desirable emotional outcomes. Emotional intelligence theory suggests that emotion regulation skills facilitate the maintenance of appropriate emotions, reducing or adapting undesirable emotions in oneself and others. Emotion regulation is usually automatic but can be controlled through learnt strategies. There is evidence that occupationally stressed individuals are less capable of down-regulating negative emotions. This paper systematically reviews studies of the role of emotion regulation in burnout in doctors.

Aims: To examine the relationship between emotion regulation and burnout among doctors.

Methods: Four online databases (Psych Info 1833-2017, Medline 1928-2017, Scopus 1960-2017 and Embase 1974-2017) were searched in August 2017. Searches returned 15,539 citations, which after de-duplication yielded 12,295 citations. After title and abstracts screening 12,273 citations were excluded. Twentytwo full text articles were read and eight excluded for ineligibility. Following data extraction, bias and methodological quality assessment, findings were synthesised using descriptive analysis and presented according to relevant themes. 
Results: A correlative relationship was observed between emotion regulation and burnout in doctors. Findings also indicated that - using self-regulatory or taught emotion regulation skills or interventions such as mindfulness were associated with a reduction in burnout.

Conclusion: Emotion regulation is an important psychological variable associated with burnout.

Key words: Burnout; emotion regulation; occupational stress; doctors; systematic review. 


\section{Introduction}

Occupational stress and burnout are known to be associated with negative workrelated outcomes such as low work satisfaction, low productivity, employee ill-health, absenteeism and higher employee attrition [1]. Within human service professions like medicine, the deleterious effects of burnout from prolonged occupational stress are well known. Among physicians, the most common causes of burnout have been reported as excessive workload and loss of control in one's work, while in surgeons, a commonly cited reason is long working hours [2].

Burnout is considered to be a psychological syndrome which usually presents with a state of physical, emotional, and mental exhaustion, often associated with diminution of the individual's ability to cope with the demands of the work environment as a result of cumulative or chronic work-related stress [3]. It is usually characterised by three components; emotional exhaustion (which can also be described as the individual's loss of passion for their work), depersonalization (where the individual treats the patient as an object), and lack of personal accomplishment (described as a sense of the individual's work no longer being meaningful) [4]. Apart from these three classic components, burnout can also present with symptoms that mimic common mental health problems such as depression [5]. Deciding whether burnout is a type of depressive condition remains a subject of continuing scientific debate [7]. What is known however is that burnout is specifically work-related, while depression can be non-specific and develop outside the context of work. What is also established on the same subject is that there are personal consequences of burnout to doctors' mental health [8]. Other established professional consequences include attrition from the profession, [9] negative impact on patient care, [10] and poor interaction with 
patients often due to poor emotion management [11]. These consequences continue to attract the attention of researchers particularly to find more effective methods of preventing the condition and managing it when it occurs.

It is believed that about a third to half of all physicians irrespective of speciality will experience at least one of the three components of burnout in their professional careers, and studies have reported that burnout in doctors often begins during undergraduate training and continues throughout postgraduate training and beyond $[12,13]$. Prevalence rates among medical students have been estimated at $50 \%$ [14], while in surgical and medical residents figures are reported to be between 50 and $76 \%$ respectively $[2,16]$. In practising physicians, prevalence rates of between 25 to $60 \%$ have been reported $[2,13]$.

Of the three components of burnout, emotional exhaustion is believed to be the first presenting symptom [3]. It is characterised by feelings of emotional depletion, extreme tiredness, lacking energy and motivation, and feeling bereft of emotional resources to cope with the continuing demands of work. It is suggested that at the point of extreme tiredness, the individual acts to preserve and regulate their energy levels, investing less effort in their work and gradually withdrawing emotionally and cognitively from it [17]. This cognitive and emotional withdrawal then progresses to depersonalisation, which presents with the individual displaying significantly detached responses to their work with a tendency to treat clients as objects [3]. In the final phase of burnout, the individual tends to evaluate himself/herself negatively, comparing their current level of competence to their competence prior to emotional exhaustion and depersonalisation. They realise they are not as effective in 
accomplishing their current work-related responsibilities, resulting in reduced personal accomplishment (characterised by a feeling of incompetence, low productivity and a feeling of lack of achievement) [3].

There are currently no known biological markers for burnout. Additionally, the underlying physiological mechanisms by which occupational stress manifests into burnout remain unclear. Emerging evidence however suggests that associations may exist between burnout and distinct alterations in the hypothalamic-pituitaryadrenal axis production of cortisol [18]. This evidence suggests that stress-related pathologies like burnout may result from dysfunction of stress response mediators in the brain. Corticotrophin Releasing Factor (CRF), a known brain neuromodulator responsible for coordinating autonomic, behavioural and cognitive responses to stress has been suggested as one such mediator thought to be a significant player in this stress response paradigm . Similarly, different convergent points for interaction (mainly within the nucleus coeruleus and dorsal raphe nucleus) have been identified for opioids/CRF, where altered balances between 'pro-stress' and 'anti-stress' systems are thought to occur [19].

Emotion regulation on the other hand describes processes by which individuals can modulate their emotions in pursuit of desirable emotional states or outcomes. In understanding the construct of emotion regulation, a description of what emotions are is vital. Historically, emotions theorists have struggled to define emotions as unitary concept and they have frequently attributed very different yet heuristic interpretations to the term. Generally however, most theorists have viewed emotions as multifaceted, whole-body responses (to relevant or personal events) which 
involve coordinated changes in bodily areas such as physiology, the subjective experience, and behaviour. From this perspective, leading emotion researchers like Gross and Thompson have described emotion regulation as goal directed processes that function to influence the intensity, duration and type of emotion experienced [20]. Emotion regulation can be categorised as an automatic (implicit) process, or an effortful (explicit) process (controlled by learnt strategies to initiate, display, maintain or modify it) [21]. Implicit regulation occurs without the individual making a conscious effort to do so, frequently initiated by simple registration of sensory inputs which in turn activate knowledge paradigms or schemas which then influence psychological functions. Explicit emotion regulation however requires volition and attention. In his influential process model of emotion regulation, Gross distinguished between two main emotion regulation strategies based on whether the strategy influences emotions at the input phase (antecedent-focused) or output phase (responsefocused). In the model, emotions may be regulated at five points during the emotion generation process; 1) situation selection (e.g. approach or avoid certain situations), 2) situation modification (e.g. tailor situation to alter its emotional impact), 3) attention deployment (e.g. distraction or concentration), 4) appraisal (e.g. cognitive change) and 5) response modulation (e.g. suppression) [20]. The first four elements of this process are antecedent-focused (i.e. occurring before fully generated emotional responses) and the last element regarded as response-focused (i.e. occurring after fully generated emotional responses). Ultimately, the process does result in emotional responses which are either lessened in severity or duration (thereby reducing deleterious or negative outcomes) or augmented (increasing such outcomes). 
Emotion regulation is also an aspect of affect regulation and it represents an important facet of the set of competencies included in human emotional intelligence. The theory of emotional intelligence suggests that individuals with greater emotion regulation skills hold wider ranges of strategies for maintaining appropriate emotions, which helps them reduce or adapt undesirable emotions in themselves and in others [22]. . In a recent functional magnetic resonance imaging study on a non-physician population, the influence of work-related chronic stress on the regulation of emotion and brain functional connectivity reported that occupationally stressed participants were less capable of down-regulating negative emotions and had altered stressprocessing limbic networks [24]. This finding suggests that occupationally stressed individuals with impaired emotion regulation ability might be more vulnerable to burnout. Evidence from the nursing profession has suggested that high levels of occupational stress are associated with low levels of emotional intelligence and selfefficacy [25]. Similar nursing evidence has found consistent inverse relationships between emotion control, its management, and burnout [26]. What remains unclear is the role of emotion regulation in burnout among doctors. The aim of this review is therefore to systematically review the literature on the relationship between emotion regulation and burnout in doctors. The review will address the question: What is the role of self-regulatory or taught emotion regulation skills or interventions in burnout among doctors.

\section{Methods}

We followed the PRISMA guidelines throughout all stages of study selection [27]. The bibliographic databases (Psych Info 1833-2017, Medline 1924-2017, Scopus 1960-2017 and Embase 1974-2017) were searched in August 2017. The subject- 
specific keywords [doctor* or physician* OR GP* OR general practitioner* OR intern* OR resident* OR registrar* OR fellow* OR consultant*] AND [burnout* OR stress* OR stress management* OR exhaust* OR occupational stress ${ }^{\star}$ ] AND [emotional affect $^{\star}$ OR emotion regulation*, OR positive affect* OR negative affect* or positive mood $^{\star}$ or negative mood* OR cognitive reappraisal or expressive suppression*] were combined separately to help identify relevant papers. Identified papers were limited to English language citations only.

Our inclusion criteria were primary quantitative studies, studies conducted in inpatient and outpatient healthcare settings, and studies published in English and in peer review journals focusing on emotion regulation in doctors and whose findings relate to burnout. Exclusion criteria included qualitative studies and systematic reviews, studies conducted in non-healthcare settings, studies not focusing on doctors or not focusing on emotion regulation in doctors, opinion-based articles, editorials, or articles focused exclusively on theoretical contributions of emotion regulation.

Our study eligibility adhered to the Population, Intervention, Comparator, Outcome (PICO) framework [28]. The study population being doctors, and interventions being self-regulatory or taught emotion regulation skills/interventions. There were no comparators and the contexts were healthcare settings. Outcomes assessed were whether emotion regulation in doctors correlated with or predicted burnout. One author (GJK) screened titles and abstracts, removed ineligible citations, and selected full text articles for inclusion in the study. A second author (PG) checked for discrepancies and disagreements were resolved through discussion. The reference lists of all eligible papers were searched for further references that had not been identified during electronic searching. Data extracted included the study author, year 
and country of publication, aim, participants, setting, design, burnout measure, emotion regulation intervention or measure, data analysis technique used, and findings reported.

We assessed risk of bias using six questions from the Critical Appraisal Tool for assessing the quality and risk of bias in Cross-Sectional studies (AXIS) [29]. The tool consists of 20 questions; seven relating to quality of reporting, seven to study design quality, and six to the possible introduction of bias. Each question in the tool requires a 'yes', 'no' or 'don't know' response. The tool does not provide a total numerical scale and therefore a degree of subjective assessment is required. The six possible introduction of bias questions used were: (1) was the selection process likely to select subjects/participants that were representative of the target/reference population under investigation, (2) were measures undertaken to address and categorise non-responders, (3) were the risk factor and outcome variables measured correctly using instruments/measurements that had been trialled, piloted or published previously, (4) does the response rate raise concerns about non-response bias, (5) If appropriate, was information about non-responders described, and (6) were the results internally consistent?

We assessed methodological quality assessment of selected studies using the 16item quality assessment tool (QATSDD) [30]. Details of the tool's psychometric properties are available elsewhere [30]. The tool consists of 16 items, 14 of which apply to both qualitative and quantitative papers, and all 16 items apply to mixed methods papers. Each of the 16 criteria are scored on a Likert scale of 0 to 3 according to whether the descriptors were present in the paper or not $(0=$ not at all, $1=$ very slightly, $2=$ moderately, and $3=$ complete). This scoring produces a 
maximum score of $48(16 \times 3)$ for mixed methods papers, and $42(14 \times 3)$ for qualitative or quantitative papers. As this study involved only quantitative studies, only 14-tool-scoring items were used. To compare quality of the papers reviewed between studies, a calculation was undertaken for each paper in percentage of the maximum possible score obtained. Data synthesis was achieved by an in-depth descriptive analysis of key findings. Meta-analysis was not undertaken because of study heterogeneity.

\section{Results}

The four electronic databases searched yielded 15,539 citations. After deduplication 12,295 citations were retuned. Titles and abstracts of the 12,295 citations were screened and 12,273 citations excluded because they did not meet the eligibility criteria. Full text articles of the remaining 22 papers were read. Eight full text papers were excluded as they did not meet the eligibility criteria. Five of the excluded studies were conducted in non-physicians, two studies had no emotion regulation measures, and one was a discussion paper on emotion regulation strategies (figure 1).

Figure 1 here

Six studies were conducted in the USA [31-36], two in Canada [37, 38], two in Italy $[39,40]$, one from Greece [41], one from Hungary [42], one from Spain [43], and one from Israel [44]. Six studies were conducted in hospital settings [31, 35, 36, 38, 40], another six in hospital and outpatient community settings [33, 34, 37, 39, 41, 42, 44], and two in primary care outpatient settings [32, 43]. All fourteen studies were of a cross-sectional design. Two of the studies used pre- and post-intervention 
approaches and involved the administration of interventions [33, 34]. Of the fourteen studies reviewed, eight involved doctors only [31-33, 35-37, 42, 43], while the study populations in six involved a combination of doctors and other healthcare professionals [34, 38-41, 44]. Eight studies examined the relationship between correlates such as mindfulness, self-regulation and intrinsic individual factors (such as positive and negative emotions) on occupational stress, burnout and professional wellbeing [31-34, 36, 37, 40, 41]. Three studies investigated how emotion regulation impacts on healthcare workers, including coping styles and use of different emotion regulation strategies and its associations with burnout [38, 39, 42, 43]. One study examined the predictors of burnout in healthcare workers [42], while another focused on the relationship between emotional intelligence and professional wellbeing and burnout [35]. Another study sought to establish the role of personal and professional factors in physician compassion fatigue [44].

\section{Table 1 here}

Regarding risk of bias assessment, participant selection processes in majority of individual studies produced representative samples [31-33, 35, 36, 42-44]. All 14 studies used previously validated measures/tools. While across all 14 studies measures used to address and categorise non-responders could have been better defined, results generally were internally consistent [31-38, 40, 42-44]. Similarly, response rates in the majority of studies were adequate. For studies with a potential for non-response bias, the main issue identified was lack of adequate information about non-responders and measures (if any) taken to address and categorise nonresponders [33, 38-42, 44]. 
The overall methodological quality of studies was good. All 14 studies achieved more than $50 \%$ of the maximum achievable quality score of 42 points. The median quality score for all studies was 25 points (60\%) The lowest scoring study achieved 22 points (52\%) [42] and the highest achieved 32 points (76\%) [43]. Three studies achieved a total quality score of $\geq 30$ points $(71 \%-76 \%) \quad[32,41,43]$, and seven studies achieved quality scores of $\geq 25-29$ points $(60 \%-69 \%)[31,33,36-38,40$, 44]. Only four studies achieved quality scores below 25 points i.e. 21 - 24 points $(52 \%-57 \%)[34,35,42]$. Main areas of methodological weaknesses across studies were lack of explicit statements regarding whether sample size calculations were considered in terms of analysis, the lack of explicit statements relating to the rationale for choice of data collection tool(s), and not making explicit evidence of user involvement in the design of studies. Individual quality ratings scores of studies are displayed in Table 3.

\section{Table 3 here}

In respect of emotion regulation interventions, taught emotion regulation skills were measured in 2 studies [37-39], and individual self-regulation skills measured in 12 studies [31, 33, 35-38, 40-42, 44]. All 12 studies which measured self-regulation skills used previously validated emotion regulation measures [31, 33, 35-44]. Regarding outcome measures, emotion regulation measures were much more heterogeneous compared with burnout measures. All fourteen burnout measures were standardised and validated [77-90]. Emotion regulation interventions/outcome measures are summarised in Table 4, and burnout measures in Table 4A.

\section{Table 4 here}


Constructs investigated which related to emotion regulation were correlates of burnout [31], antecedents and consequences of burnout [39], predictors of burnout [42], intrinsic factors associated with burnout [36], job satisfaction, professional quality of life and burnout [32], psychological wellbeing and burnout [33, 34, 37, 40, 43], positive emotions and occupational strain [41], emotional intelligence and clinician wellbeing [35], and personal/professional factors related to compassion fatigue [44]

Regarding emotion regulation as a predictor of burnout, findings from three studies $[35,37,42]$ reported predictive relationships between clinician emotion regulation and burnout. In one study, clinician's self-regulation capacity negatively predicted all three components of burnout (emotional exhaustion, depersonalization, personal accomplishment), and positively predicted psychological wellbeing in the form of personal growth, positive relationships with others, and clinician self-determination [37]. In another study [42], the strongest predictors of the emotional exhaustion component of burnout was emotional dissonance, while clinicians' display of negative emotions was predictive of depersonalization. In a third study, emotional intelligence was found to be positively predictive of wellbeing and negatively associated with two components of burnout (emotional exhaustion and depersonalization) [35].

As a correlate, emotion regulation was associated with burnout in seven studies [36, 38-41, 43, 44]. Clinicians' experience of positive emotions in one study [41] was negatively correlated with occupational strain. Similarly, another study reported that 
emotion regulation in clinicians was negatively associated with the emotional exhaustion component of burnout, but positively associated with surface acting [43]. Surface acting is an emotion regulation strategy where the individual regulates his or her emotional responses using response-focused strategies such as emotion suppression by cognitive or behavioural means, e.g. pretending to be enthusiastic about a task when that is really not the case. Surface acting was also found in another study to be positively associated with the emotional exhaustion and depersonalization components of burnout, while deep acting was positively correlated with the depersonalization component of burnout [39]. In deep acting the individual regulates the precursors of emotion using antecedent-focused strategies such as attention deployment or appraisal (cognitive change) to modify their perception of a situation, e.g. a doctor may attempt to understand a situation from a colleague's perspective as a means of modulating his or her feelings of anger toward the colleague. Higher levels of anger or loss of anger control in one study were reported to be associated with increasing burnout, and higher scores on state anger were associated with a pathological state of emotional exhaustion [40]. While taskoriented coping was found in one study to be associated with decreased risk of burnout, emotion-oriented coping in the same study was reported be associated with an increased risk of burnout [38]. Task and emotion-oriented coping are basic coping strategies by which workers manage stressful situations. In task-oriented coping the individual deals with the issue at hand using proactive measures such as outlining priorities, while with emotion-oriented coping the individual experiences emotional distress e.g. becoming tense or blaming themselves. Likewise, ability-based emotion management, trait emotional intelligence and emotion-focused coping were all found to be inversely associated with compassion fatigue in another study [44]. 
In respect of interventions, mindfulness was the commonest strategy-based emotion regulation intervention encountered in the studies reviewed. Its relationship to burnout was variously investigated in four studies [31-34]. While one study reported that trainee physicians with burnout had lower mean scores on the Cognitive and Affective Mindfulness Scale (CAMS-R) scale i.e. lower levels of mindfulness [31], another reported reduction in all three measures of burnout i.e. emotional exhaustion, depersonalization and personal accomplishment following administration of an abbreviated mindfulness intervention training. In another study which tested a hypothesis that mindfulness-based resilience training decreases burnout, no substantial short-term change in burnout parameters was reported, but there was a trend for higher perceived stress in residents (junior trainee doctors) to correlate with reduction in stress and burnout after training [33]. In a comparable study, which used a mindfulness-based stress reduction intervention, improvement was seen in all three measures of the Maslach Inventory scores i.e. emotional exhaustion, depersonalization, and personal accomplishment [34].

\section{Discussion}

Findings from this review show that emotion regulation predicts and correlates with burnout in doctors. The findings also indicated that use of self-regulatory or taught emotion regulation skills/interventions were associated with a reduction in burnout. It was also observed that emotion regulation measures used in this area of research were much more heterogeneous than expected, particularly when compared with burnout measures. This may be explained by the complexities associated with emotion regulation and its measurement, as emotion regulation is a multi- 
dimensional concept and would frequently encompass cognitive and non-cognitive facets with consequences often extending beyond just the individual.

Regarding the predictive relationship between emotion regulation and clinician burnout, the importance of emotion management skills such as self-regulation and self-management are clearly essential in the practice of medicine, to help physicians manage occupational stress and the risk of burnout much more effectively [37]. Similar findings were reported in another study where a strong predictive relationship between self-regulation capacity and enhancement in physicians' psychological wellbeing was reported [46]. In other studies, effective self-regulation/self-management skills were demonstrated to be predictive not just of health and well-being but also of enhancement in performance [47]. Taken together, these findings suggest that selfregulation capacity ensures that physicians can continue to maintain optimum physical and psychological well-being over the duration their professional careers and a proposed mechanism of self-regulation capacity within this context is the proactive regulation of emotions by the individual [48]. It is thought that this proactive regulation simultaneously protects the individual from recurring stressors or strains, and this helps them achieve external psychological well-being [48]. Some of these ideals include establishing purpose in life and environmental mastery [46]. Simon and Durand-Bush [46] argue that these two ideals have significant implications for maintaining one's position because by being able to regulate emotions in this manner, one maintains purpose and meaning in life generally, and occupationally in particular. 
The predictive role of emotional dissonance and the display of negative emotions in burnout has also garnered research attention and a recent meta-analysis reported findings in this regard, where surface acting was strongly and positively correlated with emotional exhaustion, depersonalization and psychological strain [49].

The role of mindfulness and its relationship to reduction in burnout suggests that it plays an important role in burnout. Several studies have investigated and demonstrated the usefulness of mindfulness based interventions such as Mindfulness-Based Stress Reduction (MBSR) and Mindfulness-Based Cognitive Therapy (MBCT) in decreasing emotion regulation difficulties, and thereby reducing emotional reactivity which increases an individual's ability to engage in day-to-day activity regardless of levels of emotional arousal or stresses [50]. In the context of burnout, mindfulness is thought to contribute to the enhancement of an individual's ability to derive meaning in their work through a process of self-awareness which assists in countering facets of burnout such depersonalization and emotional exhaustion [31].

Practically these findings will be beneficial to healthcare employers when planning psychological services aimed at helping prevent and manage burnout. By incorporating emotion regulation training into targeted psychological programmes, healthcare employers are likely to cultivate cohorts of doctors equipped with relevant emotion regulation and resilience skills, so that they can to cope with the relentless pressures which inevitably are associated with medical practice. Collaboration between occupational psychologists and occupational physicians might be one way of setting up such programmes. Occupational physicians could play a central role by 
identifying individuals with early signs of burnout and refer them for early intervention to ensure that this refractory distress condition is managed appropriately thereby reducing its deleterious personal and occupational impact.

Limitations of this review include acknowledgement that studies used were all conducted in English and therefore the potential for publication bias cannot be ruled out. Other limitations include the relatively small sample sizes and non-responders in some individual studies, both associated with the risk of bias in outcomes. Also notable was heterogeneity in studies, precluding metanalysis. Additionally, as studies are drawn from different countries across the world, with different healthcare systems, it is possible that physicians' emotion regulation and associated outcomes may be influenced by differing local working conditions and practice.

Future research should include clarification of the mechanisms by which positive emotions help doctors cope better with occupational stress and burnout. Similarly, studies in nursing and allied professionals are likely to be beneficial. Prospective or randomised controlled designs in future studies will also help strengthen internal validity of studies in this area.

In summary, results from this systematic review suggest a correlative relationship exists between emotion regulation and burnout in doctors. Our findings also indicate that use of self-regulatory or taught emotion regulation skills/interventions such as mindfulness are associated with a reduction in burnout in doctors. It is widely recognised in human service professions that those most vulnerable to burnout are typically those who are dedicated, highly driven, and often heavily emotionally 
involved (such as doctors), it is therefore vital that early recognition and assessment of emotion driven processes associated with their work is routinely assessed. This will ensure that appropriate psychological interventions are offered to help prevent development of burnout and associated adverse consequences such as professional attrition and risks to patient safety.

\section{Key points}

- An association exists between emotion regulation and burnout in physicians.

- Emotion regulation training is associated with a reduction in burnout.

- Appropriate emotion regulation confers positive benefits such as diminution of negative emotions and increased psychological resilience.

Acknowledgments: Non-declared

Competing Interests: None-declared

Funding: None-declared 


\section{References:}

1. Jones, F., J. Bright, and A. Clow, Stress: Myth, theory and research. 2001: Pearson Education.

2. Shanafelt, T.D., et al., Burnout and career satisfaction among American surgeons. Annals of surgery, 2009. 250(3): p. 463-471.

3. Maslach, C., W.B. Schaufeli, and M.P. Leiter, Job burnout. Annual review of psychology, 2001. 52(1): p. 397-422.

4. Maslach, C., S.E. Jackson, and M.P. Leiter, Maslach burnout inventory. 2006: CPP.

5. Brown, J.D. and L.S. Wissow, Discussion of sensitive health topics with youth during primary care visits: relationship to youth perceptions of care. The Journal Of Adolescent Health: Official Publication Of The Society For Adolescent Medicine, 2009. 44(1): p. 48-54.

6. Brown, S.D., M.J. Goske, and C.M. Johnson, Beyond Substance Abuse: Stress, Burnout, and Depression as Causes of Physician Impairment and Disruptive Behavior. Journal of the American College of Radiology, 2009. 6(7): p. 479-485.

7. Bianchi, R., I.S. Schonfeld, and E. Laurent, Burnout-depression overlap: A review. Clinical psychology review, 2015. 36: p. 28-41.

8. Ahola, K. and J. Hakanen, Job strain, burnout, and depressive symptoms: A prospective study among dentists. Journal of affective disorders, 2007. 104(1): p. 103-110.

9. Medland, J., J. Howard-Ruben, and E. Whitaker. Fostering psychosocial wellness in oncology nurses: addressing burnout and social support in the workplace. in Oncology nursing forum. 2004.

10. Shanafelt, T.D., et al., Burnout and medical errors among American surgeons. Annals of surgery, 2010. 251(6): p. 995-1000.

11. Zapf, D., et al., Emotion work as a source of stress: The concept and development of an instrument. European journal of work and organizational psychology, 1999. 8(3): p. 371-400.

12. Dyrbye, L.N., et al., Relationship between burnout and professional conduct and attitudes among US medical students. Jama, 2010. 304(11): p. 11731180 . 
13. Shanafelt, T.D., et al., Burnout and satisfaction with work-life balance among US physicians relative to the general US population. Archives of internal medicine, 2012. 172(18): p. 1377-1385.

14. Dyrbye, L.N., et al., Burnout and suicidal ideation among US medical students. Annals of internal medicine, 2008. 149(5): p. 334-341.

15. Shanafelt, T.D., Enhancing meaning in work: a prescription for preventing physician burnout and promoting patient-centered care. Jama, 2009. 302(12): p. 1338-1340.

16. Yao, D.C. and S.M. Wright, National survey of internal medicine residency program directors regarding problem residents. Jama, 2000. 284(9): p. 10991104.

17. Kleynhans, R., et al., Human Resource Management: Fresh Perspectives. Person Prentice Hall. South Africa. Page, 2006. 154.

18. Danhof-Pont, M.B., T. van Veen, and F.G. Zitman, Biomarkers in burnout: a systematic review. Journal of psychosomatic research, 2011. 70(6): p. 505524.

19. Staub, D., et al., Morphine history sensitizes postsynaptic GABA receptors on dorsal raphe serotonin neurons in a stress-induced relapse model in rats. Psychoneuroendocrinology, 2012. 37(6): p. 859-870.

20. Gross, J., The Emerging Field of Emotion Regulation: An Integrative Review. Review of General Psychology, 1998a. 2(3): p. 271-299.

21. Gross, J., G. Sheppes, and H. Urry, Cognition and emotion lecture at the 2010 SPSP Emotion Preconference: Emotion generation and emotion regulation: A distinction we should make (carefully). Cognition \& Emotion, 2011. 25(5): p. 765-781.

22. Mayer, J.D. and P. Salovey, What is emotional intelligence? In P. Salovey \& D. J. Sluyter (Eds.), Emotional development and emotional intelligence: Educational implications. 1997, New York: Harper Collins. 3-34.

23. Gross, J.J. and R.A. Thompson, Emotion regulation: Conceptual foundations. 2007.

24. Golkar, A., et al., The influence of work-related chronic stress on the regulation of emotion and on functional connectivity in the brain. PloS one, 2014. 9(9): p. e104550. 
25. El-Sayed, S.H., H.H.A. El-Zeiny, and D. Adeyemo, Relationship between occupational stress, emotional intelligence, and self-efficacy among faculty members in faculty of nursing Zagazig University, Egypt. Journal of Nursing Education and Practice, 2014. 4(4): p. 183.

26. Görgens-Ekermans, G. and T. Brand, Emotional intelligence as a moderator in the stress-burnout relationship: a questionnaire study on nurses. Journal of clinical nursing, 2012. 21(15-16): p. 2275-2285.

27. Moher, D., et al., Preferred reporting items for systematic reviews and metaanalyses: the PRISMA statement. PLoS med, 2009. 6(7): p. e1000097.

28. Schardt, C., et al., Utilization of the PICO framework to improve searching PubMed for clinical questions. BMC Medical Informatics and Decision Making, 2007. 7(1): p. 16.

29. Downes, M.J., et al., Development of a critical appraisal tool to assess the quality of cross-sectional studies (AXIS). BMJ open, 2016. 6(12): p. e011458.

30. Sirriyeh, R., et al., Reviewing studies with diverse designs: the development and evaluation of a new tool. Journal of Evaluation in Clinical Practice, 2012. 18(4): p. 746-752.

31. Chaukos, D., et al., Risk and Resilience Factors Associated with Resident Burnout. Academic Psychiatry, 2016: p. 1-6.

32. Fortney, L., et al., Abbreviated mindfulness intervention for job satisfaction, quality of life, and compassion in primary care clinicians: A pilot study. Annals of Family Medicine, 2013. 11(5): p. 412-420.

33. Goldhagen, B.E., et al., Stress and burnout in residents: impact of mindfulness-based resilience training. Adv Med Educ Pract, 2015.

34. Goodman, M.J. and J.B. Schorling, A Mindfulness Course Decreases Burnout and Improves Well-Being among Healthcare Providers. The International Journal of Psychiatry in Medicine, 2012. 43(2): p. 119-128.

35. Lin, D.T., et al., Emotional intelligence as a predictor of resident well-being. Journal of the American College of Surgeons, 2016. 223(2): p. 352-358.

36. Olson, K., K.J. Kemper, and J.D. Mahan, What Factors Promote Resilience and Protect Against Burnout in First-Year Pediatric and Medicine-Pediatric Residents? Journal of Evidence-Based Complementary \& Alternative Medicine, 2015. 20(3): p. 192-198. 
37. Gagnon, A.C., N. Durand-Bush, and B.W. Young, Self-regulation capacity is linked to wellbeing and burnout in physicians and medical students: Implications for nurturing self-help skills. International Journal of Wellbeing 2016. 6(1): p. 101-116.

38. Howlett, M., et al., Burnout in emergency department healthcare professionals is associated with coping style: a cross-sectional survey. Emergency Medicine Journal, 2015: p. emermed-2014-203750.

39. Zammuner, V.L., L. Lotto, and C. Galli, Regulation of emotions in the helping professions: Nature, antecedents and consequences. Australian e-Journal for the Advancement of Mental Health, 2003. 2(1): p. 43-55.

40. Muscatello, M.R.A., et al., Association between Burnout and Anger in Oncology versus Ophthalmology Health Care Professionals. Psychological Reports, 2006. 99(2): p. 641-650.

41. Galanakis, M., F. Galanopoulou, and A. Stalikas, Do positive emotions help us cope with occupational stress? Europe's Journal of Psychology, 2011. 7(2): p. 221-240.

42. Kovacs, M., E. Kovacs, and K. Hegedu, Emotion work and burnout: crosssectional study of nurses and physicians in Hungary. Croatian Medical Journal, 2010. 51(5): p. 432-442.

43. Martinez-Inigo, D., et al., Emotional labour and emotional exhaustion: Interpersonal and intrapersonal mechanisms. Work and Stress, 2007. 21(1): p. 30-47.

44. Zeidner, M., et al., Personal factors related to compassion fatigue in health professionals. Anxiety, Stress \& Coping: An International Journal, 2013. 26(6): p. 595-609.

45. Gross, J.J., Emotion regulation: Affective, cognitive, and social consequences. Psychophysiology, 2002. 39(3): p. 281-291.

46. Simon C and N. Durand-Bush, Does self-regulation capacity predict psychological well-being in physicians? Psychology, Health \& Medicine, 2015. 20(3): p. 311-321.

47. Bandura, A., The Primacy of Self-Regulation in Health Promotion. Applied Psychology, 2005. 54(2): p. 245-254.

48. Zimmerman, B.J., Attaining Self-Regulation-Chapter 2:A Social Cognitive Perspective. 2000: Elsevier Inc. 13-39. 
49. Hülsheger, U.R. and A.F. Schewe, On the costs and benefits of emotional labor: a meta-analysis of three decades of research. Journal of Occupational Health Psychology, 2011. 16(3): p. 361 - 389.

50. Roemer, L., S.K. Williston, and L.G. Rollins, Mindfulness and emotion regulation. Current Opinion in Psychology, 2015. 3(Supplement C): p. 52-57. 
Table 1: Summary of characteristics of studies

\begin{tabular}{|c|c|c|c|c|c|c|c|}
\hline $\begin{array}{l}\text { Author, year, } \\
\text { country }\end{array}$ & Design & $\begin{array}{l}\text { Participants \& } \\
\text { setting }\end{array}$ & Aim & Burnout measure & $\begin{array}{l}\text { Emotion regulation } \\
\text { measure/Intervention }\end{array}$ & Data analysis & Findings \\
\hline $\begin{array}{l}\text { Chaukos et al } \\
\text { 2016, USA } \\
{[31]}\end{array}$ & $\begin{array}{l}\text { Cross- } \\
\text { sectional }\end{array}$ & $\begin{array}{l}75 \text { medicine } \\
\text { and psychiatry } \\
\text { hospital } \\
\text { residents }\end{array}$ & $\begin{array}{l}\text { Examined correlates of } \\
\text { burnout prior to starting } \\
\text { clinical rotations }\end{array}$ & $\begin{array}{l}\text { Maslach Burnout } \\
\text { Inventory }\end{array}$ & $\begin{array}{l}\text { Cognitive and Affective } \\
\text { Mindfulness Scale } \\
\text { (CAMS-R) }\end{array}$ & $\begin{array}{l}\text { Chi Squared } \\
\text { tests and } \\
\text { Unpaired two- } \\
\text { tailed } t \text { tests }\end{array}$ & $\begin{array}{l}\text { Residents with } \\
\text { burnout had } \\
\text { significantly lower } \\
\text { levels of mindfulness } \\
\text { (CAMS-R } 28.5 \pm 6.6 \\
\text { vs. } 32.5 \pm 6.3, t-2.3 \\
\text { p }<0.05, d=-0.63 \text { ) }\end{array}$ \\
\hline $\begin{array}{l}\text { Fortney et al., } \\
\text { 2013, USA } \\
{[32]}\end{array}$ & $\begin{array}{l}\text { Cross- } \\
\text { sectional }\end{array}$ & $\begin{array}{l}30 \text { physicians } \\
\text { working in } \\
\text { primary care }\end{array}$ & $\begin{array}{l}\text { Investigated abbreviated } \\
\text { mindfulness intervention } \\
\text { pre/post training and } \\
\text { increases job satisfaction, } \\
\text { quality of life and } \\
\text { compassion }\end{array}$ & $\begin{array}{l}\text { Maslach Burnout } \\
\text { Inventory }\end{array}$ & $\begin{array}{l}\text { Abbreviated mindfulness } \\
\text { intervention }\end{array}$ & $\begin{array}{l}\text { Linear mixed- } \\
\text { effect model } \\
\text { analysis }\end{array}$ & $\begin{array}{l}\text { Reductions in all } \\
\text { measures of burnout: } \\
\text { Emotional } \\
\text { exhaustion } \mathrm{p}<0.001 \text {, } \\
\text { depersonalization } \mathrm{p}< \\
0.005, \text {, personal } \\
\text { accomplishment } \mathrm{P}< \\
0.001 \text { ) }\end{array}$ \\
\hline $\begin{array}{l}\text { Gagnon et al., } \\
\text { 2016, Canada } \\
\text { [37] }\end{array}$ & $\begin{array}{l}\text { Cross- } \\
\text { sectional }\end{array}$ & $\begin{array}{l}25 \text { Physicians } \\
\text { and } 37 \text { medical } \\
\text { students in } \\
\text { hospitals and } \\
\text { community } \\
\text { settings }\end{array}$ & $\begin{array}{l}\text { Investigated relationship } \\
\text { between self-regulation, } \\
\text { psychological wellbeing } \\
\text { and burnout }\end{array}$ & $\begin{array}{l}\text { Maslach Burnout } \\
\text { Inventory }\end{array}$ & $\begin{array}{l}\text { Self-regulation } \\
\text { Questionnaire }\end{array}$ & $\begin{array}{l}\text { Hierarchical } \\
\text { regression } \\
\text { analyses }\end{array}$ & $\begin{array}{l}\text { Self-regulation } \\
\text { capacity positively } \\
\text { predicted } \\
\text { psychological } \\
\text { wellbeing (personal } \\
\text { growth } B=0.49 \text {, } \\
\text { positive relationships } \\
\text { with others } B=0.46 \text {, } \\
\text { autonomy } B=0.43 \text { ) } \\
\text { and negatively } \\
\text { predicted burnout } \\
\text { (emotional } \\
\text { exhaustion } B=-0.45 \text {, } \\
\text { depersonalization } B= \\
-0.30 \text {, personal } \\
\text { accomplishment } B=- \\
0.56 \text { ) }\end{array}$ \\
\hline $\begin{array}{l}\text { Galanakis et } \\
\text { al., 2011, } \\
\text { Greece [41] }\end{array}$ & $\begin{array}{l}\text { Cross- } \\
\text { sectional }\end{array}$ & $\begin{array}{l}2775 \\
\text { professionals } \\
\text { from public and }\end{array}$ & $\begin{array}{l}\text { Investigated relationship } \\
\text { between positive emotions } \\
\text { and occupational strain }\end{array}$ & $\begin{array}{l}\text { Occupational Stress } \\
\text { Inventory }\end{array}$ & $\begin{array}{l}\text { Differential Emotion } \\
\text { Scale- Modified }\end{array}$ & $\begin{array}{l}\text { Correlation and } \\
\text { regression } \\
\text { analyses }\end{array}$ & $\begin{array}{l}\text { Experiencing positive } \\
\text { emotions is } \\
\text { negatively correlated }\end{array}$ \\
\hline
\end{tabular}




\begin{tabular}{|c|c|c|c|c|c|c|c|}
\hline & & $\begin{array}{l}\text { private sectors } \\
\text { including } 71 \\
\text { medical } \\
\text { doctors }\end{array}$ & & & & & $\begin{array}{l}\text { with occupational } \\
\text { strain } \\
(r=-0.53, p<0.01)\end{array}$ \\
\hline $\begin{array}{l}\text { Goldhagen et } \\
\text { al., 2015, [33] } \\
\text { USA }\end{array}$ & $\begin{array}{l}\text { Cross- } \\
\text { sectional: } \\
\text { pre/ post } \\
\text { intervention } \\
\text { prospective } \\
\text { study }\end{array}$ & $\begin{array}{l}47 \text { residents } \\
\text { (before } \\
\text { intervention), } \\
30 \text { residents } \\
\text { (after } \\
\text { intervention) } \\
\text { from hospital } \\
\text { and primary } \\
\text { care settings }\end{array}$ & $\begin{array}{l}\text { Test hypothesis that a } \\
\text { mindfulness-based } \\
\text { resilience intervention } \\
\text { would decrease stress and } \\
\text { burnout }\end{array}$ & $\begin{array}{l}\text { Oldenberg Burnout } \\
\text { Inventory (OLBI) }\end{array}$ & $\begin{array}{l}\text { Mindfulness-based } \\
\text { resilience activities } \\
\text { measured with } \\
\text { Mindfulness Attention } \\
\text { Awareness Scale }\end{array}$ & $\begin{array}{l}\text { Kruskal-Wallis } \\
\text { and Wilcoxon } \\
\text { signed rank } \\
\text { tests }\end{array}$ & $\begin{array}{l}\text { No significant short- } \\
\text { term change in } \\
\text { stress or burnout, but } \\
\text { there was a trend for } \\
\text { higher perceived } \\
\text { residency stress to } \\
\text { correlate with } \\
\text { reduction in stress } \\
\text { and burnout after } \\
\text { intervention (OLBI } \\
\text { disengagement } \\
\text { subscale } p<0.05 \text {, }\end{array}$ \\
\hline $\begin{array}{l}\text { Goodman \& } \\
\text { Schorling } \\
\text { 2012, USA } \\
\text { [34] }\end{array}$ & $\begin{array}{l}\text { Cross- } \\
\text { sectional: } \\
\text { pre/ -\& post } \\
\text { intervention } \\
\text { study }\end{array}$ & $\begin{array}{l}93 \text { healthcare } \\
\text { providers } \\
\text { including } 51 \\
\text { physicians } \\
\text { from university } \\
\text { and community } \\
\text { settings }\end{array}$ & $\begin{array}{l}\text { Determine if mindfulness- } \\
\text { based stress reduction } \\
\text { could decrease burnout } \\
\text { and improve wellbeing }\end{array}$ & $\begin{array}{l}\text { Maslach Burnout } \\
\text { Inventory }\end{array}$ & $\begin{array}{l}\text { Mindfulness Based } \\
\text { Stress Reduction } \\
\text { Programme }\end{array}$ & $\begin{array}{l}T \text { tests and } \\
\text { Chi-squared } \\
\text { tests }\end{array}$ & $\begin{array}{l}\text { Maslach Burnout } \\
\text { Inventory scores } \\
\text { improved after the } \\
\text { MBSR programme } \\
\text { (emotional } \\
\text { exhaustion } p<0.05 \text { ), } \\
\text { depersonalization } \\
(p<0.05) \text {, personal } \\
\text { accomplishment } \\
\text { ( }<<0.001) \text { and } \\
\text { mental wellbeing } \\
(p<0.001)\end{array}$ \\
\hline $\begin{array}{l}\text { Howlett at al., } \\
\text { 2015, Canada } \\
\text { [38] }\end{array}$ & $\begin{array}{l}\text { Cross- } \\
\text { sectional }\end{array}$ & $\begin{array}{l}616 \\
\text { healthcare, } \\
\text { including } 43 \\
\text { physicians' } \\
\text { professionals } \\
\text { within a } \\
\text { hospital setting }\end{array}$ & $\begin{array}{l}\text { Examined relationship } \\
\text { between coping styles and } \\
\text { burnout }\end{array}$ & $\begin{array}{l}\text { Maslach Burnout } \\
\text { Inventory }\end{array}$ & $\begin{array}{l}\text { Coping Inventory for } \\
\text { Stressful Situations } \\
\text { (CISS) }\end{array}$ & $\begin{array}{l}\text { Regression } \\
\text { analyses }\end{array}$ & $\begin{array}{l}\text { Task oriented coping } \\
\text { associated with } \\
\text { decreased risk of } \\
\text { burnout, whiles } \\
\text { emotion-oriented } \\
\text { coping associated } \\
\text { with increased risk of } \\
\text { burnout }\end{array}$ \\
\hline $\begin{array}{l}\text { Kovacs et al., } \\
2010, \\
\text { Hungary [42] }\end{array}$ & $\begin{array}{l}\text { Cross- } \\
\text { sectional }\end{array}$ & $\begin{array}{l}186 \text { healthcare } \\
\text { workers from } \\
\text { in-and- } \\
\text { outpatient } \\
\text { services } 80 \\
\text { physicians }\end{array}$ & $\begin{array}{l}\text { Investigate predictors of } \\
\text { burnout in healthcare } \\
\text { workers }\end{array}$ & $\begin{array}{l}\text { Maslach Burnout } \\
\text { inventory }\end{array}$ & $\begin{array}{l}\text { Frankfurt Emotion Work } \\
\text { Scale - Hungarian } \\
\text { version }\end{array}$ & $\begin{array}{l}\text { Independent } T \\
\text { tests and } \\
\text { regression } \\
\text { analyses }\end{array}$ & $\begin{array}{l}\text { Strongest predictors } \\
\text { of burnout were } \\
\text { emotional } \\
\text { dissonance for } \\
\text { emotional exhaustion } \\
(B=0.401) \text {, and }\end{array}$ \\
\hline
\end{tabular}




\begin{tabular}{|c|c|c|c|c|c|c|c|}
\hline & & & & & & & $\begin{array}{l}\text { display of negative } \\
\text { emotions for } \\
\text { depersonalization } \\
(B=0.332)\end{array}$ \\
\hline $\begin{array}{l}\text { Lin et al., } \\
\text { 2016, USA } \\
\text { [35] }\end{array}$ & $\begin{array}{l}\text { Cross- } \\
\text { sectional }\end{array}$ & $\begin{array}{l}73 \text { hospital } \\
\text { residents }\end{array}$ & $\begin{array}{l}\text { Understand the } \\
\text { relationship between } \\
\text { emotional intelligence and } \\
\text { wellness among surgical } \\
\text { residents }\end{array}$ & $\begin{array}{l}\text { Maslach Burnout } \\
\text { Inventory }\end{array}$ & $\begin{array}{l}\text { Emotional Intelligence } \\
\text { Questionnaire - short } \\
\text { form }\end{array}$ & $\begin{array}{l}\text { Multivariate } \\
\text { regression } \\
\text { analyses }\end{array}$ & $\begin{array}{l}\text { Emotional } \\
\text { intelligence strongly } \\
\& \text { positively } \\
\text { predictive of } \\
\text { wellbeing ( } B=0.76 ; \\
\text { p<0.001), and } \\
\text { negatively with } \\
\text { emotional exhaustion } \\
(B=-0.63 ; 0.001), \\
\text { depersonalization } \\
(B=-0.48 ; p<0.05) \\
\text { and depression }(B=- \\
0.60 ; p<0.001)\end{array}$ \\
\hline $\begin{array}{l}\text { Martínez- } \\
\text { Íñigo 2007, } \\
\text { Spain [43] }\end{array}$ & $\begin{array}{l}\text { Cross- } \\
\text { sectional }\end{array}$ & $\begin{array}{l}345 \text { primary } \\
\text { care General } \\
\text { Practitioners }\end{array}$ & $\begin{array}{l}\text { Examined how use of } \\
\text { different emotion regulation } \\
\text { strategies relates to } \\
\text { doctor's emotional } \\
\text { exhaustion }\end{array}$ & $\begin{array}{l}\text { Maslach Burnout } \\
\text { Inventory }\end{array}$ & Emotion Labour Scale & $\begin{array}{l}\text { Hierarchical } \\
\text { multiple } \\
\text { regression }\end{array}$ & $\begin{array}{l}\text { Emotion regulation } \\
\text { negatively } \\
\text { associated with } \\
\text { emotional exhaustion } \\
\mathrm{F}(6,322)=24.05, \mathrm{~B} \\
=-0.12, \mathrm{p}<0.01) \\
\text { but positively } \\
\text { associated with } \\
\text { surface acting } \mathrm{F} \\
(6,324)=25.82, B= \\
0.17, \mathrm{p}<0.01) \text { and } \\
\text { neutral with deep } \\
\text { acting }\end{array}$ \\
\hline $\begin{array}{l}\text { Muscatello et } \\
\text { al., 2006, Italy } \\
{[40]}\end{array}$ & $\begin{array}{l}\text { Cross- } \\
\text { sectional }\end{array}$ & $\begin{array}{l}68 \text { healthcare } \\
\text { professionals } \\
\text { including } \\
\text { medical } \\
\text { oncologists, } \\
\text { medical } \\
\text { oculists and } \\
\text { nurses in a } \\
\text { hospital setting }\end{array}$ & $\begin{array}{l}\text { Evaluate prevalence of } \\
\text { anger emotions in } \\
\text { oncology staff and its } \\
\text { correlation with burnout } \\
\text { compared with staff in } \\
\text { ophthalmology }\end{array}$ & $\begin{array}{l}\text { Maslach Burnout } \\
\text { Inventory }\end{array}$ & $\begin{array}{l}\text { State-Trait Anger } \\
\text { Expression Inventory }\end{array}$ & $\begin{array}{l}\text { Correlational } \\
\text { and regression } \\
\text { analysis }\end{array}$ & $\begin{array}{l}\text { Correlational } \\
\text { analysis showed that } \\
\text { higher anger/loss of } \\
\text { anger control } \\
\text { associated with } \\
\text { increasing burnout. } \\
\text { Higher scores on } \\
\text { State Anger } \\
\text { associated with }\end{array}$ \\
\hline
\end{tabular}




\begin{tabular}{|c|c|c|c|c|c|c|c|}
\hline & & & & & & & $\begin{array}{l}\text { pathological state of } \\
\text { Emotional } \\
\text { exhaustion (OR: } \\
1.17,95 \% \mathrm{Cl}=1.04- \\
1.32)\end{array}$ \\
\hline $\begin{array}{l}\text { Olson et al., } \\
\text { 2015, USA } \\
{[36]}\end{array}$ & $\begin{array}{l}\text { Cross- } \\
\text { sectional }\end{array}$ & $\begin{array}{l}45 \text { first year } \\
\text { paediatric and } \\
\text { medicine- } \\
\text { paediatric } \\
\text { residents in a } \\
\text { hospital setting }\end{array}$ & $\begin{array}{l}\text { Test a conceptual model } \\
\text { that defined selected } \\
\text { intrinsic factors that are } \\
\text { related to burnout }\end{array}$ & $\begin{array}{l}\text { Maslach Burnout } \\
\text { Inventory }\end{array}$ & $\begin{array}{l}\text { The Five Facet } \\
\text { Mindfulness } \\
\text { Questionnaire and Neff's } \\
\text { Self-Compassion Scale }\end{array}$ & $\begin{array}{l}\text { Pearson } \\
\text { correlations } \\
\text { and analyses } \\
\text { of variance }\end{array}$ & $\begin{array}{l}\text { Self-compassion and } \\
\text { mindfulness } \\
\text { positively associated } \\
\text { with resilience } \\
(r=0.37, p<0.05) \& \\
(r=0.38, p<0.05) \\
\text { respectively. Self- } \\
\text { compassion and } \\
\text { mindfulness } \\
\text { inversely associated } \\
\text { with burnout }(r=- \\
0.35, p<0.05) \&(r=- \\
0.33, p<0.05) \\
\text { respectively }\end{array}$ \\
\hline $\begin{array}{l}\text { Zammuner et } \\
\text { al 2003, Italy } \\
\text { [39] }\end{array}$ & $\begin{array}{l}\text { Cross- } \\
\text { sectional }\end{array}$ & $\begin{array}{l}180 \text { hospital } \\
\text { employees } \\
\text { including } \\
\text { doctors and } \\
\text { nurses }\end{array}$ & $\begin{array}{l}\text { Investigate how emotion } \\
\text { regulation affects } \\
\text { healthcare workers' jobs, } \\
\text { the kinds of emotion } \\
\text { regulation processes } \\
\text { needed, } \\
\text { antecedents/consequences } \\
\text { and whether emotional } \\
\text { labour might be a causal }\end{array}$ & $\begin{array}{l}\text { Maslach Burnout } \\
\text { Inventory }\end{array}$ & Emotional Labour Scale & $\begin{array}{l}\text { Correlational } \\
\text { analysis }\end{array}$ & $\begin{array}{l}\text { Surface acting } \\
\text { positively associated } \\
\text { with emotional } \\
\text { exhaustion }(r=0.31, \\
p<0.01) \text { and } \\
\text { depersonalization } \\
(r=0.21, p<0.01) \text { and } \\
\text { negatively with } \\
\text { deactivated affect }\end{array}$ \\
\hline
\end{tabular}




\begin{tabular}{|c|c|c|c|c|c|c|c|}
\hline & & & component of burnout & & & & $\begin{array}{l}(\mathrm{r}=-0.23, \mathrm{p}<0.01) \\
\text { Deep acting } \\
\text { positively correlated } \\
\text { with } \\
\text { depersonalization } \\
(\mathrm{r}=0.15, \mathrm{p}<0.05) \text { and } \\
\text { negatively correlated } \\
\text { with social } \\
\text { desirability }(\mathrm{r}=-0.26 \text {, } \\
\mathrm{p}<0.01)\end{array}$ \\
\hline $\begin{array}{l}\text { Zeidner et al } \\
2013 \text {, Israel } \\
{[44]}\end{array}$ & $\begin{array}{l}\text { Cross- } \\
\text { sectional }\end{array}$ & $\begin{array}{l}83 \text { mental } \\
\text { health } \\
\text { practitioners } \\
\text { and } 93 \\
\text { physicians } \\
\text { from seven } \\
\text { hospitals and } \\
\text { six private } \\
\text { clinics }\end{array}$ & $\begin{array}{l}\text { Investigated the role of } \\
\text { personal and professional } \\
\text { factors in compassion } \\
\text { fatigue }\end{array}$ & $\begin{array}{l}\text { Professional Quality } \\
\text { of Life Scale - } \\
\text { (Compassion } \\
\text { Satisfaction/Fatigue } \\
\text { Subscales) }\end{array}$ & $\begin{array}{l}\text { Emotion Management } \\
\text { Subscale of the Mayer- } \\
\text { Salovey-Caruso } \\
\text { Emotional Intelligence } \\
\text { Test }\end{array}$ & MANCOVA & $\begin{array}{l}\text { Ability-based } \\
\text { emotion } \\
\text { management }(B=- \\
0.18, t=-2.35, p< \\
0.01) \text { and trait } \\
\text { emotional } \\
\text { intelligence }(B=- \\
0.18, \mathrm{t}=-2.29, \mathrm{p}< \\
0.05), \\
\text { were inversely } \\
\text { associated with } \\
\text { compassion fatigue. } \\
\text { Emotion focused } \\
\text { coping was inversely } \\
\text { related to } \\
\text { compassion fatigue } \\
(B=0.56, t=8.52, p< \\
0.01)\end{array}$ \\
\hline
\end{tabular}


Table 2: Risk of bias assessment (can be made available as supplementary data at Occupational Medicine on line)

\begin{tabular}{|c|c|c|c|c|c|c|}
\hline $\begin{array}{l}\text { Risk of bias } \\
\text { questions } \longrightarrow \\
\text { Studies } \\
\downarrow\end{array}$ & $\begin{array}{c}\text { Was the selection } \\
\text { process likely to } \\
\text { select } \\
\text { subjects/participants } \\
\text { that were } \\
\text { representative of the } \\
\text { target/reference } \\
\text { population under } \\
\text { investigation? }\end{array}$ & $\begin{array}{c}\text { Were } \\
\text { measures } \\
\text { undertaken to } \\
\text { address and } \\
\text { categorise } \\
\text { non- } \\
\text { responders? }\end{array}$ & $\begin{array}{c}\text { Were the risk factor and } \\
\text { outcome variables measured } \\
\text { correctly using } \\
\text { instruments/measurements } \\
\text { that had been trialled, piloted } \\
\text { or published previously? }\end{array}$ & $\begin{array}{l}\text { Does the } \\
\text { response } \\
\text { rate raise } \\
\text { concerns } \\
\text { about non- } \\
\text { response } \\
\text { bias? }\end{array}$ & $\begin{array}{c}\text { If } \\
\text { appropriate, } \\
\text { was } \\
\text { information } \\
\text { about non- } \\
\text { responders } \\
\text { described? }\end{array}$ & $\begin{array}{l}\text { Were the results } \\
\text { internally consistent? }\end{array}$ \\
\hline Chaukos et al 2016 & + & $\neq$ & + & - & - & + \\
\hline Fortney et al 2013 & + & $\neq$ & + & - & + & + \\
\hline Gagnon et al 2016 & - & $\neq$ & + & - & + & + \\
\hline Galanakis et al 2011 & - & $\neq$ & + & $\neq$ & $\neq$ & $\neq$ \\
\hline Goldhagen et al 2015 & + & $\neq$ & + & + & - & + \\
\hline $\begin{array}{l}\text { Goodman \& Schorling } \\
2012\end{array}$ & $\neq$ & $\neq$ & + & - & + & + \\
\hline Howlett et al 2015 & - & $\neq$ & + & + & - & + \\
\hline Kovacset al 2010 & + & $\neq$ & + & + & - & + \\
\hline Lin et al 2016 & + & $\neq$ & + & - & - & + \\
\hline Martínez-Íñigo 2007 & + & $\neq$ & + & - & - & + \\
\hline Muscatello et al 2006 & - & $\neq$ & + & $\neq$ & - & + \\
\hline Olson et al 2015 & + & $\neq$ & + & - & - & + \\
\hline Zammuner et al 2003 & $\neq$ & $\neq$ & + & $\neq$ & - & $\neq$ \\
\hline Zeidner et al 2013 & + & $\neq$ & + & $\neq$ & - & + \\
\hline
\end{tabular}

Key: Yes $=+$, No $=-$, Don't know $=\neq$ 
Table 3: Quality rating scores of studies (can be made available as supplementary data at Occupational Medicine on line)

\begin{tabular}{|c|c|c|c|c|c|c|c|c|c|c|c|c|c|c|}
\hline \multirow[b]{2}{*}{$\begin{array}{c}\text { Study reference } \rightarrow \\
\text { Quality assessment criteria } \\
\downarrow\end{array}$} & \multicolumn{14}{|c|}{$\begin{array}{c}\text { Scoring of quality rating } \\
0=\text { Not at all, } 1=\text { Very slightly, } 2=\text { Moderate, } 3=\text { Complete } \\
(\text { Maximum possible score }=42)\end{array}$} \\
\hline & [31] & [32] & [37] & [41] & [33] & [34] & [38] & [42] & [35] & [43] & {$[40]$} & [36] & [39] & {$[44]$} \\
\hline Explicit theoretical framework & 1 & 1 & 3 & 3 & 2 & 1 & 3 & 2 & 3 & 3 & 3 & 1 & 1 & 2 \\
\hline $\begin{array}{l}\text { Statement of aims/objectives in main body } \\
\text { of report }\end{array}$ & 2 & 3 & 3 & 3 & 1 & 2 & 2 & 3 & 3 & 3 & 3 & 3 & 3 & 1 \\
\hline Clear description of research setting & 3 & 3 & 3 & 2 & 3 & 2 & 3 & 1 & 3 & 3 & 3 & 3 & 1 & 2 \\
\hline $\begin{array}{l}\text { Evidence of sample size considered in } \\
\text { terms of analysis }\end{array}$ & 1 & 1 & 0 & 1 & 3 & 0 & 0 & 0 & 0 & 0 & 0 & 0 & 0 & 0 \\
\hline $\begin{array}{l}\text { Representative sample of target group of a } \\
\text { reasonable size }\end{array}$ & 3 & 3 & 3 & 3 & 3 & 3 & 3 & 3 & 2 & 3 & 2 & 2 & 3 & 3 \\
\hline Description of procedure for data collection & 3 & 3 & 1 & 3 & 2 & 3 & 1 & 1 & 2 & 3 & 2 & 2 & 2 & 2 \\
\hline Rationale for choice of data collection tool(s) & 1 & 3 & 1 & 1 & 1 & 0 & 1 & 0 & 0 & 1 & 1 & 1 & 3 & 2 \\
\hline Detailed recruitment data & 2 & 3 & 3 & 2 & 1 & 2 & 1 & 1 & 2 & 3 & 2 & 2 & 2 & 2 \\
\hline $\begin{array}{l}\text { Statistical assessment of reliability and } \\
\text { validity of measurement tool(s) }\end{array}$ & 0 & 1 & 1 & 3 & 0 & 0 & 2 & 2 & 0 & 3 & 1 & 2 & 1 & 2 \\
\hline $\begin{array}{l}\text { Fit between stated research question and } \\
\text { method of data collection }\end{array}$ & 3 & 3 & 3 & 3 & 3 & 3 & 3 & 3 & 3 & 3 & 2 & 3 & 3 & 3 \\
\hline $\begin{array}{l}\text { Fit between research question and method } \\
\text { of analysis }\end{array}$ & 3 & 3 & 3 & 3 & 3 & 3 & 3 & 3 & 3 & 3 & 3 & 3 & 3 & 3 \\
\hline $\begin{array}{l}\text { Good justification for analytic method } \\
\text { selected }\end{array}$ & 1 & 2 & 2 & 0 & 3 & 1 & 2 & 1 & 1 & 2 & 1 & 1 & 1 & 1 \\
\hline Evidence of user involvement in design & 0 & 0 & 0 & 0 & 1 & 0 & 1 & 0 & 0 & 0 & 0 & 0 & 0 & 0 \\
\hline Strengths and limitations critically discussed & 2 & 2 & 1 & 3 & 3 & 2 & 2 & 2 & 2 & 2 & 2 & 2 & 1 & 2 \\
\hline Total quality score (Maximum score $=42$ ) & 25 & 31 & 27 & 30 & 29 & 22 & 27 & 22 & 24 & 32 & 25 & 25 & 24 & 25 \\
\hline $\begin{array}{l}\text { Comparison of quality scores in (\%) } \\
\text { percentage }\end{array}$ & $59.5 \%$ & $73.8 \%$ & $64.2 \%$ & $71.4 \%$ & $69.0 \%$ & $52.3 \%$ & $64.2 \%$ & $52.3 \%$ & $64.2 \%$ & $76.1 \%$ & $59.5 \%$ & $59.5 \%$ & $57.1 \%$ & $59.5 \%$ \\
\hline
\end{tabular}

Key: Chaukos et al 2016, USA [31], Fortney et al., 2013, USA [32], Gagnon et al., 2016, Canada [37], Galanakis et al., 2011, Greece [41], Goldhagen et al., 2015, USA [33], Goodman \& Schorling 2012, USA [34], Howlett at al., 2015, Canada [38], Kovacs et al., 2010, Hungary [42], Lin et al., 2016, USA [35],Martínez-Ínigo 2007, Spain [43], Muscatello et al., 2006, Italy [40], Olson et al., 2015, USA [36], Zammuner et al 2003, Italy [39], Zeidner et al 2013, Israel [44] 



\section{Figure 1: Flow of citations through the review process}
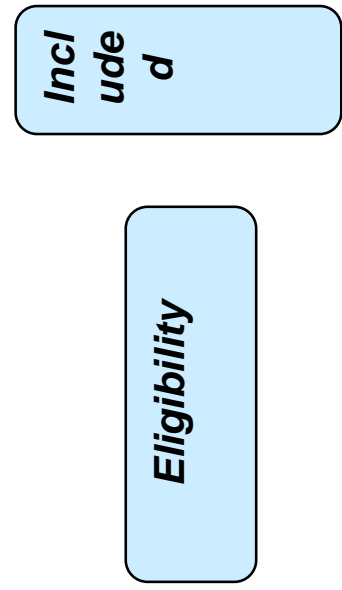

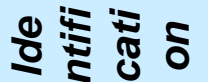

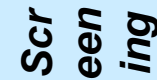

Records identified through four database searches

$(n=15,539)$
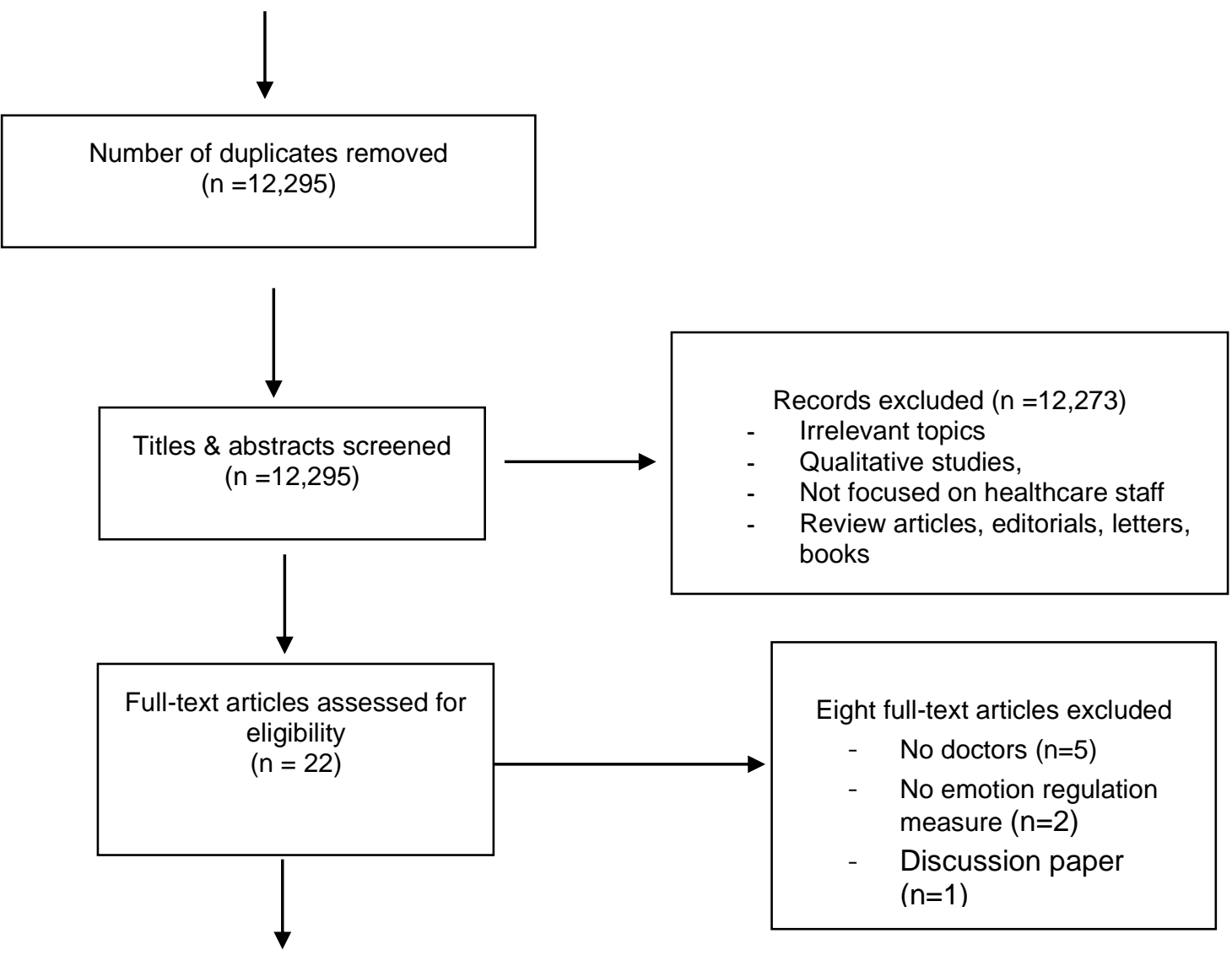

Studies eligible for inclusion $(n=14)$

No additional citations identified through hand searches of references of $(n=14)$ selected studies

Number of studies included in

final review

$(n=14)$ 
Appendix 4: Emotion regulation measures (can be made available as supplementary data at Occupational Medicine on line)

\begin{tabular}{|c|c|}
\hline Type of measure/intervention & Number of studies \\
\hline Abbreviated mindfulness intervention programme & $1[78]$ \\
\hline Mindfulness-based stress reduction programme & $1[82]$ \\
\hline Emotional Labour Scale & $2[86,89]$ \\
\hline Cognitive and Affective Mindfulness Scale & $1[31]$ \\
\hline Self-regulation Questionnaire & $1[37]$ \\
\hline Differential Emotion Scale-Modified & $1[41]$ \\
\hline Mindfulness Attention Awareness Scale & $1[33]$ \\
\hline Coping Inventory for Stressful Situations & $1[38]$ \\
\hline $\begin{array}{c}\text { Frankfurt Emotion Work Scale - Hungarian } \\
\text { version }\end{array}$ & $1[42]$ \\
\hline Emotional Intelligence Questionnaire - short form & $1[35]$ \\
\hline State-Trait Anger Expression Inventory & $1[40]$ \\
\hline $\begin{array}{l}\text { Five Facet Mindfulness Questionnaire and Neff's } \\
\text { Self-Compassion Scale }\end{array}$ & $1[36]$ \\
\hline $\begin{array}{l}\text { Emotion Management Subscale of the Mayer- } \\
\text { Salovey-Caruso Emotional Intelligence Test }\end{array}$ & $1[44]$ \\
\hline
\end{tabular}


Appendix 4A: Burnout measures (can be made available as supplementary data at Occupational Medicine on line)

\begin{tabular}{|c|c|}
\hline Type of measure & Number of studies \\
\hline Maslach Burnout Inventory & $11[31,32,34,35,37-40,42,43]$ \\
\hline Occupational Stress Inventory & $1[41]$ \\
\hline Oldenberg Burnout Inventory & $1[33]$ \\
\hline Professional Quality of Life Scale & $1[44]$ \\
\hline
\end{tabular}

